\title{
Effect of service quality and motivation on the consumption behavior of students in the academic services
}

\author{
Kuswanto, Irzal Anderson \\ Faculty of Teacher Training and Education, University of Jambi, Indonesia
}

\begin{tabular}{l}
\hline \hline Article Info \\
\hline Article history: \\
Received Jun 11, 2020 \\
Revised Dec 26, 2020 \\
Accepted Jan 30, 2021 \\
\hline
\end{tabular}

Keywords:

Consumer behavior

Consumption motivation

Service quality

\begin{abstract}
This study aimed to determine the effect of service quality and motivation to the consumption behavior of students in utilizing academic services. This research involved 87 students of Economic Education Study Program in University of Jambi, Indonesia. The data were analyzed using structural equation modeling with partial least squares technique (SEM-PLS). Student consumption behavior is an illustration of the level of satisfaction in utilizing academic services provided by universities. Satisfaction with academic services is a measure of the success of higher education performance in providing education. A good indicator of consumer behavior variables, namely making the University of Jambi academic services the best choice and choosing them as institutions of higher education to meet learning needs on an ongoing basis. The quality of academic services is shown by indicators of the reliability of officers in providing academic services, accuracy in the delivery of information, responsiveness in responding to complaints and student requests and harmonization of service relationships between officers and students. While consumption motivation is indicated by an indicator of trust in the services consumed it will facilitate the completion of academic affairs and the existence of attractive offers from higher education institutions. The quality of academic services has a significant effect on consumer behavior of students. Moreover, the consumption motivation variable is proven to be a significant mediator on the effect of service quality on student's consumption behavior.
\end{abstract}

This is an open access article under the CC BY-SA license.

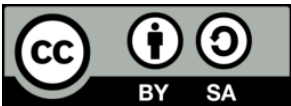

\section{Corresponding Author:}

Kuswanto

Economic Education Study Program

Faculty of Teacher Training and Education

University of Jambi

J1. Jambi-Ma. Bulian KM.15 Mendalo Indah, Jambi, Indonesia

Email: kuswanto.fkip@unja.ac.id

\section{INTRODUCTION}

Academic service is the main type of service provided to students by any academic institution. The functioning of academic services is not only determined by the performance of the institution, but is largely determined by the role of the service user (students). Integration of the interests of the institution with the interests of students becomes the energy to realize quality services. The aim of every institution is to provide excellent academic services in order to realize quality academic processes and produce quality output [1]. The concern of institutions and students in realizing shared interests will shape a conducive culture or work atmosphere. If the academic work culture has developed positively in the tertiary environment, it will create a conducive atmosphere and make academic services run effectively [2]. 
A positive academic culture illustrates the active involvement of students in using academic services and the effective functioning of all academic components in providing services to students. The condition of academic culture illustrates the distance of power between students and institutions, efforts to avoid uncertainty, and individualism. Cultural conditions followed by consumption intentions largely determine consumer behavior [3].

The active involvement of students in using academic services is shown by their behavior towards the benefits of academic services they receive. As consumers (service users), student behavior shows various activities in obtaining and using goods or services, as well as the decision making process and determining the activities to be carried out [4]. Moreover, this behavior is characterized by the efforts of consumers to identify problems, find information, evaluate alternatives, and make purchasing decisions [5]. Consumption behavior is related to individual reasons and the pressure to determine selection, make purchases, use products or services to meet their needs [6].

Student behavior in using academic services will also be seen in the ways in which decisions are made in utilizing resources such as money, time, and effort to obtain goods or services to be consumed [7]. Indirectly, consumer behavior is built from the perception of the services to be used. If consumers perceived that the use of services are convenient and practical, they become more confident towards the benefits that they may get from these services and thus, they develop positive consumer behavior towards the academic services [8]. Uncontrolled consumer behavior and deviating towards the negative will have bad consequences for these consumers, namely not achieving the goal of consumption [9].

University of Jambi is one of the tertiary institutions that plays a role in realizing the quality of human resources, both at the local and national/international level. Community access to education organized by tertiary institutions illustrates the level of competitiveness of the tertiary institution. Higher education institutions that have a high level of competitiveness have a high level of demand for education, both at the local, national and international levels. One of the goals of ISO standardization in the academic services of the Teaching and Education Faculty (TEF) of University of Jambi is to become an institution of higher education that is sought by the international community. The decision of the community to choose University of Jambi as a place of learning is based on their perceived assurance that the university canfulfill their desired academic needs through the various services it provides.

Academic services at tertiary institutions generally include lecture activities, academic guidance, final project guidance (thesis and dissertation), study monitoring, final semester assessment and administration and graduation. To support the academic implementation, the higher education provides facilities and infrastructure services such as libraries, laboratories, and ICT. Academic services are provided to students as an effort to meet their academic needs so as to get satisfaction in learning [10]. Students who have a high desire to succeed in their academic fields will try to make the most of available academic services. Consumption is the activity of using goods or services to achieve maximum satisfaction [11]. However, the motivation will weaken if students do not get satisfaction from the services they use. Increasing the motivation for consumption is the company's interest in increasing sales. To increase the motivation must be created, made aware of or reinforced needs in the minds of consumers [12]. There are efforts made by companies to increase consumption motivation both from within and from outside consumers.

The quality of academic services illustrates the image of higher education institutions [13]. Students who are satisfied with academic services provided by higher education institutions will continue their education at the university and will promote quality academic services to others which eventually increases stakeholders' confidence to the university [14]. The stakeholders' trust in the higher education institution will highly depend on the satisfaction of the students, because all the processes implicating the quality of inputs, processes, and outputs are applied to them [15]. Providing quality academic services will encourage students to establish mutually beneficial relationships in the long run [16]. The quality of academic services will provide employee and lecturer satisfaction at work, which in turn, will have a direct impact on college performance. The higher the quality of academic services, the more students decide to choose learning, both in terms of curriculum content, lecture process, evaluation and coaching [17]. Students who feel satisfaction with the academic services obtained will tend to continue higher education in the same study program.

Consumer behavior is not only influenced by price, product, promotion, and distribution channels, but by various psychological, cultural, social, and personal factors [18]. Psychological factors emphasize the existence of an impulse from within consumers to decide to use a product or avail a service. Consumers are motivated to use a good or service because they have a need that can be met by the company, a product that can improve its appearance and there are attractive offers from the company [19]. The higher the motivation of consumers the higher the decision to make a purchase of an item.

Various studies on consumer (student) behavior are not carried out specifically on the goods or services consumed [20-25]. Student consumption behavior is viewed from the general satisfaction obtained with the consumption of goods or services, so that it does not provide a clear picture of the effect of 
satisfaction manifested by specific consumption as a student. This research has revealed various variables that determine student consumption behavior, such as parents' socioeconomic background, economic education in the family, economic literacy, peers, and lifestyle. The same research also examines student consumption behavior not based on consumption of more specific goods [26]. Student consumption behavior is analyzed using virtual variables, namely student income, preferences, and advertising factors. Other studies examine consumer behavior in students from the perspective of microeconomic and macroeconomic theories [27].

One research on consumer behavior of students that is more specific to the consumption of academic services was conducted by Kurbani [28]. Consumer behavior in this study is a form of student satisfaction from the academic services they consumed. Student satisfaction is assessed in terms of the variables that influence it, namely the quality of academic services and educational facilities. More specific studies of consumer (student) behavior are on green consumption, which is a form of response to damage of environmental resources where they look for products and services that cause the least amount of environmental damage [29]. Research on consumer behavior in students focuses more on cultural values and consumption styles that are reflected in this behavior [30]. Student consumption behavior is assessed based on their functional food consumption [31].

From previous studies, an analysis of student consumption behavior would be more realistic if it focused on the types of goods or services consumed. Research on students' consumption behavior in utilizing academic services will provide an overview of the performance of higher education in organizing education. The success rate of higher education is not only determined by the number of graduates produced, but is largely determined by the absorption of the world of work for the graduates produced. Student access to academic services ensures that the learning process runs effectively because all the components are functioning. Therefore, an in-depth study of the quality of academic services provided by universities is needed that will motivate students to utilize it optimally and eventually help them develop positive attitude towards these academic services.

In this study, the effect of the quality of academic services, mediated by consumption motivation, on student behavior in utilizing academic services as a measure of the performance of higher education in organizing education was investigated. This study complements previous studies in strengthening the assumption of the effect of service quality and consumption motivation on student consumption behavior in utilizing academic services.

\section{RESEARCH METHOD}

\subsection{Research design}

This study examined the effect of service quality and consumption motivation on students' consumption behavior in using academic services. Consumer behavior is a form of student satisfaction from using educational services provided by higher education institutions. The service will function optimally if students have high motivation in using it. Thus, consumption motivation becomes a mediating variable that influences service quality on consumer (student) behavior. To analyze this case, structural equation modeling (SEM) was implemented. Through this model, factor analysis and path analysis were implemented simultaneously and determined the relationship between exogenous and endogenous variables with all the indicators [32]. By using SEM, the relationship model is not only determined or estimated but will also be evaluated [33]. To get the best estimate of each indicator block on each latent variable, the linear model of latent variables is analyzed using partial least structural equation modeling (SEM-PLS).

\subsection{Population and sample}

This research was conducted among the 6th semester of the University of Jambi, Economic Education Study Program involving 87 respondents. Subject selection was carried out purposively with the sampling method developed by Taherdoost [34] and Ethikan [35], which is based on the level of use of education services both in quantity and quality, so that it reflects more realistic consumption behavior. Students enrolled in the 6th semester were considered to have used educational services a lot and have the potential to be researched because, in general, they are still actively participating in learning activities. Some of these characteristics justified the determination of subjects in this study.

\subsection{Research instruments}

The research instrument used to obtain data from each variable studied in the form of a questionnaire arranged according to the indicators of these variables. Service quality is measured based on indicators of tangibility, reliability, responsiveness, assurance, and empathy [36, 37]. Indicators of consumption motivation are modified from various studies [38-40], namely the existence of needs that can be met from the education services consumed, from the belief that education services consumed will facilitate 
the completion of academic affairs, and the existence of attractive offers from higher education institutions. Indicators used to measure consumer behavior are based on Kotler and Armstrong's theory [41], namely problem recognition, information search, alternative evaluation, decision to use services and post-service behavior. Matrices are explained in Table 1.

Table 1. Indicators of the research variables of the study

\begin{tabular}{|c|c|c|}
\hline Variable & Indicator & Code \\
\hline Consumer & a. Introduction to academic service problems & $\mathrm{CB} 1$ \\
\hline \multirow[t]{4}{*}{ behavior } & b. Information search for academic services & $\mathrm{CB} 2$ \\
\hline & c. Evaluate alternative academic services & CB3 \\
\hline & d. Decision to use academic services & CB4 \\
\hline & e. Post-use academic service behaviour & CB5 \\
\hline \multirow{16}{*}{$\begin{array}{l}\text { Quality of } \\
\text { service }\end{array}$} & a. Tangibility & \\
\hline & - Complete facilities & QS1 \\
\hline & - Convenience of academic facilities & QS2 \\
\hline & - Appearance of academic Officers & QS3 \\
\hline & b. Reliability & \\
\hline & - Suitability and timeliness of service & QS4 \\
\hline & - Reliability of academic service officers & QS5 \\
\hline & - Accuracy in delivering information & QS6 \\
\hline & c. Responsiveness & \\
\hline & - Be responsive in responding to student complaints and requests & QS7 \\
\hline & d. Guarantee & \\
\hline & - Competency of academic service officers & QS8 \\
\hline & e. Empathy & \\
\hline & - Service officer responsibilities & QS9 \\
\hline & - Attitudes of service officers & QS10 \\
\hline & - Harmonization of service relations between officers and students & QS11 \\
\hline \multirow{3}{*}{$\begin{array}{l}\text { Motivation of } \\
\text { consumption }\end{array}$} & a. Believing that the academic needs of the educational services consumed are being met & CM1 \\
\hline & b. Believing that the consumed educational services will facilitate the completion of academic affairs & $\mathrm{CM} 2$ \\
\hline & c. An attractive offer from a tertiary institution & CM3 \\
\hline
\end{tabular}

\subsection{Data analysis method}

In this study, data were analyzed using the SEM-PLS approach, which is an estimation model that has a formative construct, explaining the relationship between first order and second order as the indicator. This model was chosen because it does not require the following assumptions: large numbers of samples, multivariate normal distribution, and model to meet goodness of fit [42]. Data were analyzed using SmartPLS software version 3.2.8.

The measurement model includes the relationship between the indicators of each variable with the first-order construct measured by the indicator and the second-order construct with the first-order construct as the indicator. The assessment of the resulting model is based on criteria according to Chin [42] and relevant studies, such as Richter [43], as explained in Table 2.

Table 2. Criteria for measurement of the reflective model

\begin{tabular}{ll}
\hline \multicolumn{1}{c}{ Criteria } & \multicolumn{1}{c}{ Information } \\
\hline Composite reliability & The composite reliability is a measure of internal consistency and must not be lower than 0.6 \\
Indicator reliability & Absolute standardized outer (component) loadings should be higher than 0.7 \\
Average variance extracted (AVE) & AVE should be higher than 0.5 \\
Loading factor & The loading factor value must be above 0.70. \\
Discriminant validity & The square root value of AVE must be greater than the correlation value between latent \\
& variables. \\
Cross loading & Each indicator block is expected to have a higher loading for each latent variable compared \\
& to other latent variable variables \\
\hline
\end{tabular}

\section{RESULTS}

\subsection{Test model quality measurement}

A model can be used as a good predictor if the forming indicators have high validity and reliability values. The assessment of the model used is assessed in two stages, namely evaluating the construct of the first order formed by the indicators and evaluating the second order construct formed by the first order. As a rule of thumb, an indicator is said to be a good variable measure if the outer loadings are above 0.70 [42, 43].

The results of the outer loadings test in Table 3 shows values below 0.70 on the indicators CB1 (introduction to problems of academic services), CB2 (information search for academic services), CM1 
(believing the fulfillment of academic needs of educational services consumed), QS1 (completeness of facilities ), QS1 (completeness of facilities), QS2 (convenience of academic facilities), QS3 (appearance of academic officers), QS4 (compliance and timeliness of service), QS8 (competency of academic service officers), QS9 (responsibility of service officers) and QS10 (attitude service officer). These indicators were eliminated and not included in hypothesis testing.

The results of the analysis of the validity of discrimination show the level of difference in the concept of each construct or latent variable with other variables. If the value of the construct correlation with the measurement items is greater than the value of the correlation with the construct, then the model has good discriminant validity [44]. Table 4 explains the level of validity of the discriminant model that was analyzed. Based on Table 4, it is explained that the correlation values of all constructs are greater than the correlation values with other constructs, so that the overall construct or latent variable used in the model has good discriminant validity. By using AVE method, it can also be seen the level of discriminant validity of each construct or latent variable. If the AVE value is greater than 0.5 , it shows a good validity value [32]. The AVE value obtained from processed research data is as shown in Table 5.

Table 3. Test results for outer loadings

\begin{tabular}{cccc}
\hline Variables/Indicators & Consumer behavior & Consumer motivation & Quality service \\
\hline CB1 & 0.582 & & \\
CB2 & 0.542 & & \\
CB3 & 0.783 & & \\
CB4 & 0.788 & & \\
CB5 & 0.805 & 0.698 & \\
CM1 & & 0.786 & \\
CM2 & & 0.804 & \\
CM3 & & \\
QS1 & & 0.479 \\
QS10 & & 0.584 \\
QS11 & & 0.756 \\
QS2 & & & 0.556 \\
QS3 & & 0.696 \\
QS4 & & 0.578 \\
QS5 & & 0.747 \\
QS6 & & 0.757 \\
QS7 & & 0.772 \\
QS8 & & & 0.630 \\
QS9 & & & \\
& & & \\
\hline
\end{tabular}

Table 4. Validity of discrimination of the variables in the study

\begin{tabular}{cccc}
\hline Variable & Consumer behavior & Consumer motivation & Quality service \\
\hline Consumer behavior & 0.709 & & \\
Consumer motivation & 0.633 & 0.764 & \\
Quality service & 0.480 & 0.522 & 0.663 \\
\hline
\end{tabular}

Table 5. AVE value

\begin{tabular}{|c|c|c|c|c|}
\hline Variable & Cronbach's Alpha & Rho_A & Composite reliability & AVE \\
\hline Consumer behavior & 0.754 & 0.799 & 0.831 & 0.503 \\
\hline Consumer motivation & 0.644 & 0.655 & 0.808 & 0.584 \\
\hline Quality service & 0.869 & 0.887 & 0.894 & 0.401 \\
\hline
\end{tabular}

\subsection{Hypothesis test}

Hypotheses were tested using path coefficient values, t-statistics and p-values. If the path coefficient value is between -0.1 to 0.1 , then it is not significant. If the p-value is less than 0.05 , it is not significant [45]. Therefore, the hypothesis is accepted if the path coefficient value is greater than 0.1 and the p-value is smaller than 0.05 . The path coefficient values and p-values which were used for hypothesis testing decisions in this study are shown in Table 6. 
Table 6. Direct effects direct effects of consumer motivation on consumer behavior, service quality on consumer behavior and service quality on consumer motivation

\begin{tabular}{cccccc}
\hline Variable & $\begin{array}{c}\text { Original } \\
\text { samples }(\mathrm{O})\end{array}$ & $\begin{array}{c}\text { Sample } \\
\text { averages }(\mathrm{M})\end{array}$ & $\begin{array}{c}\text { Standard } \\
\text { deviation }\end{array}$ & t statistics & p values \\
\hline Consumer motivation $\rightarrow$ Consumer behavior & 0.419 & 0.425 & 0.094 & 4.477 & 0.000 \\
Quality service $\rightarrow$ Consumer behavior & 0.310 & 0.313 & 0.098 & 3.156 & 0.002 \\
Quality service $\rightarrow$ Consumer motivation & 0.531 & 0.544 & 0.066 & 8.011 & 0.000 \\
\hline
\end{tabular}

Hypothesis 1 states that the quality of academic services has a direct effect on consumer behavior. Test results on the path coefficient between the quality of academic services with consumer behavior indicate the existence of a path coefficient of 0.31 which is greater than 0.1 and significant at $\alpha=0.05$, thus hypothesis 1 is accepted.

Hypothesis 2 states that consumption motivation has a direct effect on consumer behavior. The test results on the path coefficient between consumption motivation and consumer behavior indicate a path coefficient of 0.419 which is greater than 0.1 and significant at $\alpha=0.05$, thus hypothesis 2 is accepted.

Based on the level of significance of the influence of service quality and consumption motivation on the consumption behavior of these students, it supports the assumption that the main effect of the independent variable on the dependent variable must be fulfilled significantly, so that the test of mediation effects can be carried out [46].

Hypothesis 3 states that the quality of academic services directly influences consumer behavior through consumption motivation. Based on Table 7, the test results on the path coefficient between academic service quality and consumer behavior indicate through consumption motivation that there is a path coefficient of 0.222 which is greater than 0.1 and significant at $\alpha=0.05$, as seen in Table 7 , thus hypothesis 3 is accepted.

Table 7. Indirect effects of service quality on consumer behavior through consumer motivation

\begin{tabular}{|c|c|c|c|c|c|}
\hline Variable & $\begin{array}{l}\text { Original } \\
\text { samples }\end{array}$ & $\begin{array}{c}\text { Sample } \\
\text { averages }\end{array}$ & $\begin{array}{l}\text { Standard } \\
\text { deviation }\end{array}$ & T statistics & $P$ values \\
\hline Quality service $\rightarrow$ Consumer motivation $\rightarrow$ Consumer behavior & 0.222 & 0.232 & 0.062 & 3.599 & 0.000 \\
\hline
\end{tabular}

\subsection{Structural model evaluation}

The coefficient of determination shows the ability of the model to predict the influence of the exogenous variable(s) to the endogenous variable. The model is considered weak as a predictor if the value of $\mathrm{R}^{2}$ is less or equal to 0.19 [42]. The model is considered moderate if the $\mathrm{R}^{2}$ value is 0.33 , and the model is considered strong as a predictor if the value of $R^{2}$ is equal to or greater than 0.67 . The $R^{2}$ values generated from the PLS program are shown in Table 8.

Table 8 shows that the $\mathrm{R}^{2}$ value for the consumer behavior variable is 0.725 . The coefficient of determination explains that the ability of the model to predict the effect of service quality and consumption motivation variables on consumer behavior is 72.5 percent. The value of $\mathrm{R}^{2}$ for the consumption motivation variable is 0.557 , explaining that the effect caused by the service quality variable on consumption motivation is 55.7 percent. Thus, it can be concluded that both models can moderately predict the relationship between the concerned variables.

Table 8. Structural model evaluation

\begin{tabular}{ccc}
\hline Variable & R square & Adjusted R square \\
\hline Consumer behavior & 0.725 & 0.719 \\
Consumer motivation & 0.557 & 0.552 \\
\hline
\end{tabular}

\subsection{Path coefficient $(\beta)$}

The path coefficients in the research model in Table 9 how that all paths have coefficient values in the range of 0.050 to 0.735 . Path coefficient values that range in the range of -0.1 to 0.1 are considered insignificant, values greater than 0.1 are significant and directly proportional, and values smaller than -0.1 is a significant value and inversely proportional [45]. Based on the results of PLS output, as shown in Table 9, it appears that all lines have coefficient values of more than 0.100 . More concisely, the results of the analysis of the estimated PLS model can be illustrated in Figure 1. 


\begin{tabular}{cccccc} 
Table 9. Model path coefficients & & \\
\hline Variable & $\begin{array}{c}\text { Original } \\
\text { samples }\end{array}$ & $\begin{array}{c}\text { Sample } \\
\text { averages }\end{array}$ & $\begin{array}{c}\text { Standard } \\
\text { deviation }\end{array}$ & T statistic & P values \\
\hline Consumer motivation $\rightarrow$ Consumer behavior & 0.419 & 0.425 & 0.094 & 4.477 & 0.000 \\
Quality service $\rightarrow$ Consumer behavior & 0.310 & 0.313 & 0.098 & 3.156 & 0.002 \\
Quality service $\rightarrow$ Consumer motivation & 0.531 & 0.544 & 0.066 & 8.011 & 0.000 \\
\hline
\end{tabular}

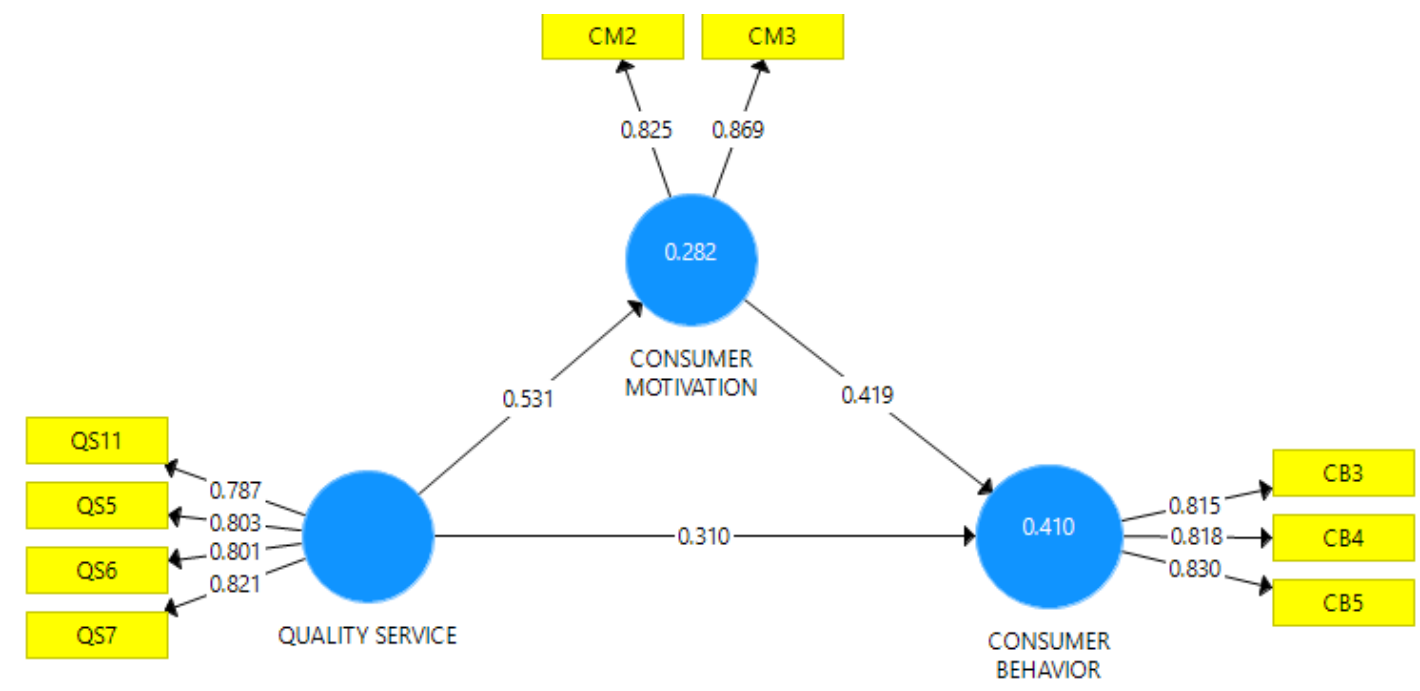

Figure 1. Path diagram of influence of service quality on consumer behavior through consumption motivation variables

\section{DISCUSSION}

\subsection{Effect of service quality on consumer behavior (students)}

Based on the analysis using the SEM-PLS approach, the service quality variable has a positive and significant effect with a path coefficient of 0.31 . That is, if the academic service quality score increases by 10 units, student satisfaction in using the service will increase by 3.1 units. Some indicators of the quality of academic services that contribute to influencing student consumption behavior are the reliability of officers in providing academic services, accuracy in the delivery of information, responsiveness in responding to complaints and requests of students, and harmonization of service relations between officers and students. These results explain that students want academic services provided by the University of Jambi to have quality standards as indicated by these indicators and students do not take into account other academic service indicators such as the completeness of facilities, comfort of academic facilities, the appearance of academic officials, suitability and timeliness of services, academic staff service competencies, service officer responsibilities and service staff attitudes. The results of this study are relevant to research [1], it is just that the results of the study prioritize the quality-of-service availability for space to support student activities and the availability of books and teaching materials related to the syllabus.

The results of this study are also supported by findings [15] which state that students' perceptions of service quality are positively correlated with the satisfaction of using those services. Other research results that are also relevant to this research are research conducted by [28]. Where the results of the analysis confirm the existence of a positive and significant effect between the quality of academic services on student satisfaction with sig values $0.046<\alpha(0.05)$.

Thus, it can be concluded that service quality is a determining factor in student satisfaction in utilizing academic services. This satisfaction is manifested in its behavior which makes the University of Jambi's academic service the best choice as an institution that is believed to be able to meet the learning needs carried out consistently.

\subsection{Effect of consumption motivation on consumer behavior (students)}

The results of the PLS model analysis show the consumption motivation variable have a positive and significant effect on student behavior in utilizing academic services. The path coefficient of influence was obtained at 0.419 . That is, if the consumption motivation score increases by 10 units, it will increase student satisfaction scores in utilizing academic services by 4.19 units. Consumption motivation shows the 
existence of students' encouragement in utilizing academic services. Students who have high motivation in utilizing academic services will increasingly show positive behavior towards academic services provided by the University of Jambi. Indicators of student consumption motivation that contribute to influencing behavior in utilizing academic services are the belief in the services consumed that will facilitate the completion of academic affairs and the existence of attractive offers from higher education institutions. That is, students are more motivated to use academic services provided by the University of Jambi because it is based on these indicators, while the other indicators are considered less reflective of their desires.

This supports same assumption form previous studies that the intention of students to consume has a significant influence on consumer behavior and their prospective purchasing decisions [47]. Other research findings that also reinforce this finding shows that consumer behavior is influenced by their needs and other factors such as brand design, product quality and product image [48].

In contrast to the research conducted [49], consumer purchase motivation is influenced by behavior even though the results are not significant. The results of previous research [6] shows a conflicting finding, where psychological factors negatively affect consumer behavior. This happens because students who have a better perception of the function of items cause consumption behavior to be negative.

Based on the above findings and some of the previous research results, it can be concluded that the consumption motivation factor greatly determines student satisfaction in utilizing academic services provided by the University of Jambi. Students who believe in the credibility of academic services and the existence of attractive offers from higher education institutions will form positive behavior in utilizing the academic services.

\subsection{Effect of service quality on consumer behavior (student) through consumption motivation variables}

The results of the analysis using the PLS model show a mediating effect caused by the consumption motivation variable in shaping the effect of service quality on consumer behavior (student). These results explain that the quality of academic services will influence consumer behavior (student) if the student is motivated to take advantage of academic services provided by higher education institutions. In another sense, even though academic services are of high quality, students are less motivated to use them, so they will not form positive consumer (student) behavior.

The results of this study are supported by research conducted by Gunawan [50], where consumption motivation and attitude are very significant factors affecting consumer behavior. Mensah [51] in his research also proved the same effect of service quality on customer satisfaction. It's just that in this study service quality was tested as a moderating variable the effect of customer satisfaction on purchase intentions. The results explain that this variable cannot moderate the effect of being tested. Different findings from the SEM analysis show that service quality variables do not significantly affect customer satisfaction, but do not influence purchasing decisions [52].

Based on the results of this study, explaining that the quality of academic goals desired by students to higher education institutions is the reliability of officers in providing academic services, accuracy in the delivery of information, responsiveness in responding to complaints and requests of students, and harmonization of service relationships between officers and students. The quality of academic services will form positive consumption behavior if students believe the academic services that are utilized will facilitate the completion of academic affairs and the existence of attractive offers from higher education institutions. Students who are satisfied with academic services will make the University of Jambi academic services the best choice and choose them as educational institutions to meet their learning needs in the next period.

\section{CONCLUSION}

Quality academic services are expected to increase satisfaction of students in utilizing these services provided by any educational institution. The quality of academic services becomes meaningful in shaping positive consumer behavior if it is supported by the motivation of students to use it. Based on the results of this study, it can be concluded that the dominant consumption behavior exhibited by students is to make the University of Jambi's academic service the best choice as a higher education institution to meet learning needs on an ongoing basis. The quality of academic services that are highly expected by students from higher education institutions is the reliability of officers in providing academic services, accuracy in the delivery of information, responsiveness in responding to complaints, and requests of students as well as the harmonization of service relations between officers and students. While the very dominant consumption motivation shown by students in utilizing academic services is the belief in the services consumed that will facilitate the completion of academic affairs and the existence of attractive offers from higher education institutions. 
The results of the SEM-PLS analysis also concluded that the satisfaction of students in utilizing academic services is strongly influenced by the quality of service and is supported by the motivation to use it. This finding confirms that quality academic services will function if students are motivated to use them. Consumption motivation mediates the effect of service quality on student consumption behavior in utilizing academic services. These findings are very beneficial to higher education institutions in improving academic service performance, which does not only focused on improving service quality, but needs to improve its academic relationships with students in particular and to all stakeholders in general so as to form a synergy of the interests of service users with service providers in one vision and mission of higher education institutions. Nevertheless, in-depth studies are still needed on the formation of positive student consumption behavior as part of the parameters of the performance of higher education institutions in providing academic services, namely by involving other variables.

\section{ACKNOWLEDGEMENTS}

The author would like to thank the Dean of FKIP and the Rector of University of Jambi for facilitating this research. The author also thanks students who cooperatively provide the data and information needed in this study.

\section{REFERENCES}

[1] Suroto, et al., "Students' Satisfaction on Academic Services in Higher Education Using Importance-Performance Analysis," ComTech, vol. 8, no. 1, pp. 37-43, 2017.

[2] E. Indrayani, "Management of Higher Education Academic Information Systems Based on Information and Communication Technology (ICT) (in Bahasa)," Jurnal Penelitian Pendidikan, vol. 12, no. 1, pp. 45-40, 2011.

[3] K. B. Mulyono, "Cultural Influences, Social Factors, Consumption Learning, and Consumer Attitudes toward Consumer Behavior through Consumer Intentions in Semarang City High School Students (in Bahasa)," Journal of Economic Education, vol 3, no. 2, pp. 1-7, 2014.

[4] B. Swastha, Introduction to Modern Business, Introduction to Modern Corporate Economics (in Bahasa). Jakarta: Liberty, 2000.

[5] P. Kotler and K. L. Keller, Marketing Management, Volume 1 (B. Sabran, Trans.). Jakarta: Erlangga, 2008.

[6] Sunanik, "An Analysis of Factors That Influenced Students' Consumption Behavior at STKIP PGRI Tulungagung," IOSR Journal of Business and Management (IOSR-JBM), vol. 18, no. 11, pp. 15-20, 2016, doi: 10.9790/487X-1811011520.

[7] Schiffman and Kanuk, Consumer Behavior, 7th Ed. Jakarta: Indeks, 2008.

[8] Christina, et al., "Analysis of Acceptance and Use of Ojek Online Technology with TAM (in Bahasa)," Jurnal Pendidikan Ekonomi \& Bisnis, vol. 6, no. 1, pp. 34-45, 2018, doi: 10.21009/JPEB.006.1.4.

[9] A. Arianto and J. Sojanah, "Financial Literacy as an Effort to Improve Parent Role on Children Consumer Behavior," International Journal of Research \& Review, vol. 6, no. 8, pp. 113-119, 2019.

[10] K. Azan, et al., "Academic Service Quality (in Bahasa)," Jurnal Administrasi Pendidikan, vol. 22, no. 1, pp. 190-203, 2015.

[11] Enrico, et al., "The Factors that Influenced Consumptive Behavior: A Survey of University Students in Jakarta," International Journal of Scientific and Research Publications, vol. 4, no. 1, pp. 1-6, 2014

[12] P. Rani, "Factors influencing consumer behavior," Int. J. Curr. Res. Aca. Rev, vol. 2, no. 9, pp. 52-61, 2014.

[13] J. Kumar and C. L. Yang, "Service Quality and Loyalty of International Students Studying in The Field of Hospitality and Tourism," Malaysian Online Journal of Educational Management, vol. 2, no. 3, pp. 97-118, 2014.

[14] D. Supriadi, and U. S. Sa'ud, "The Effectiveness Of Implementing Information And Communication Technology On Student Academic Services (A Case Study in Bandung Institute of Technology for the 2015-2016 Period)," International Journal of Education, vol. 9, no. 2, pp. 139-148, 2017, doi: 10.17509/ije.v9i2.5478.

[15] A. Azam, "Service Quality Dimensions and Students' Satisfaction: A study of Saudi Arabian Private Higher Education Institutions," European Online Journal of Natural and Social Sciences, vol. 7, no. 2, pp. 275-284, 2018.

[16] R. Siram, "Higher Education Academic Service Quality Assurance Management (in Bahasa)," Jurnal Ilmu Pendidikan, vol. 21, no. 1, pp. 54-58, 2015.

[17] A. Sufiyyah, "The Effect of Academic and Bureaucratic Service Quality on Student Satisfaction (in Bahasa)," Jurnal Aset, vol. 13, no. 2, pp. 85-93, 2011.

[18] Engel, et al., Consumer Behavior, Volume 1 (Budiyanto, trans.). Jakarta: Binarupa Aksara. 1994.

[19] K. Y. H. Miauw, "Consumer Motivation and Consumer Attitudes toward Buying Decisions in the Wild (in Bahasa)," PERFORMA: Jurnal Manajemen dan Start-Up Bisnis, vol. 1, no. 5, pp. 568-575, 2016.

[20] W. Aprillia, et al., "The Influence of Parents' Social Economic Background, Economic Education in the Family and Economic Literacy on Student Consumption Behavior (in Bahasa)," Jurnal Pendidikan Humaniora, vol. 3, no. 1, pp. 78-84, 2015

[21] V. Drifanda, "The Effect of Economic Literacy and Peers on Consumption Behavior of Students in Economic Education at the University of PGRI Semarang (in Bahasa)," EQUILIBRIA Pendidikan Jurnal Ilmiah Pendidikan Ekonomi, vol. 3, no. 1, 36-42, 2018. 
[22] R. P. F. Astuti, "The Influence of Parents' Social Economic Status, Economic Literacy and Life Style on Consumption Behavior of Students of the Department of Economic Education IKIP PGRI Bojonegoro (in Bahasa)," Jurnal EDUTAMA, vol. 3, no. 2, pp. 49-58, 2016.

[23] N. Lisma and A. Haryono, "Analysis of Student Consumption Behavior in Terms of Transaction Motive (Case Study in S1 Economics Education Students, Faculty of Economics, State University of Malang, Force of 2012) (in Bahasa),"JPE, vol. 9, no. 1, pp. 42-50, 2016.

[24] R. Mulyani, P. Thomas, and W. Widiyanto, "The Influence of Student Consumption, Social Status of Family, the Economic Parent Status, and the Economic Education of Family to Consumption Behavior," J. of Econ. Educ., vol. 7, no. 1, pp. 24-30, 2018.

[25] N. Ardyanti and Kardoyo, "Determinants of Consumption Behavior Among Students," Dinamika Pendidikan, vol. 13, no. 1, pp. 30-41, 2018, doi: 10.15294/dp.v13i1.15112.

[26] J. Li and F. Chen, "Analysis of College students' consumption behavior based on Virtual variable regression," International Journal of Latest Research in Engineering and Technology (IJLRET), vol. 04, no. 03, pp. 05-09, 2018.

[27] H. Monika, "Consumer Behavior of College Students in the Czech Republic," Journal of Competitiveness, vol. 7, no. 4, pp. 68-85, 2015, doi: 10.7441/joc.2015.04.05.

[28] A. Kurbani, "The Effect of Academic Service Quality and Educational Facilities on Student Satisfaction at the University of PGRI Palembang (in Bahasa)," Jurnal Media Wahana Ekonomika, vol. 13, no. 4, pp. 22-35, 2017.

[29] C. H. Huang, et al., "An Investigation of College Students' Green Consumption Behavior in China," International Journal of e-Education, e-Business, e-Management and e-Learning, vol. 7, no. 4, pp. 280-286, 2017, doi: 10.17706/ijeeee.2017.7.4.280-286.

[30] F. Wang and S. Xu, "Impact of Cultural Values on Consumption Behavior: A Survey of Contemporary Chinese University Students," Intercultural Communication Studies, vol. 18, no. 1, pp. 260, 2009.

[31] S. Afina and Retnaningsi, "The Influence of Students' Knowledge and Attitude toward Functional Foods Consumption Behavior," Journal of Consumer Sciences, vol. 03, no. 1, pp. 1-14, 2018.

[32] A. Ghozali, Structural Equation Modeling: Metode alternatif dengan Partial Least Square (PLS), 4th ed. Semarang: Badan Penerbit Universitas Diponegoro, 2014.

[33] G. Evangelos and Y. Siskos, Customer satisfaction evaluation, vol. 1, no. 139. Springer US, 2010.

[34] H. Taherdoost, "Sampling Methods in Research Methodology; How to Choose a Sampling Technique for Research," International Journal of Academic Research in Management (IJARM), vol. 5, no. 2, pp. 18-27, 2016.

[35] I. Etikan, S. Abubakar Musa, and R. Sunusi Alkassim, "Comparison of Convenience Sampling and Purposive Sampling," American Journal of Theoretical and Applied Statistics, vol. 5, no. 1, pp. 1-4, 2015, doi: 10.11648/j.ajtas.20160501.11.

[36] P. A. D. Mattah and A. J. Kwarteng, "Indicators of service quality and satisfaction among graduating students of a higher education institution (HEI) in Ghana," Higher Education Evaluation and Development, Emerald Publishing Limited, vol. 12, no. 1, pp. 36-52, 2018, doi: 10.1108/HEED-10-2017-0006.

[37] M. Pakurar, H. Haddad, J. Nagy, J. Popp, and J. Oláh, “The Service Quality Dimensions that Affect Customer Satisfaction in the Jordanian Banking Sector," Sustainability, vol. 11, no. 4, 2019.

[38] A. M. Lee and H. I. Chyi, "Motivational Consumption Model: Exploring the Psychological Structure of News Use," Journalism \& Mass Communication Quarterly, vol. 91, no. 4, pp. 706-724, 2014, doi: $10.1177 / 1077699014550088$

[39] M. Blaskova, et al., "Sustainable Academic Motivation," Sustainability, vol. 11, no. 21, pp. 1-24, 2019, doi: $10.3390 / \mathrm{su} 11215934$

[40] N. Hasan, S. Alam Malik and M. Majid Khan, "Measuring Relationship Between Students' Satisfaction and Motivation in Secondary Schools of Pakistan," Middle-East Journal of Scientific Research, vol. 18, no. 7, pp. 907-915, 2013.

[41] P. Kotler and G. Armstrong, Marketing Principles, Volume 1. Erlangga, Jakarta, 2008.

[42] W. W. Chin, "The Partial Least Squares Aproach to Structural Equation Modeling," Modern Methods for Business Research, vol. 295, no. 336, 1998.

[43] N. F. Richter, G. A. Cepeda Carrion, J. L. Roldán, and C. Marc Ringle, "European management research using Partial Least Squares Structural Equation Modeling (PLS-SEM)," European Management Journal, vol. 34, no. 6, pp. 589-714, 2016.

[44] H. Latan and I. Ghozali, Partial Least Squares: Konsep, Teknik, dan Aplikasi Menggunakan Program SmartPLS 2.0 M3. Semarang: Badan Penerbit Universitas Diponegoro, 2012.

[45] N. Hass and F. Lehner, "Knowledge Management Success Factors-Proposal of an Empirical Research," Electronic Journal of Knowledge Management, vol. 8, no. 1, pp. 79-90, 2010.

[46] R. M. Baron and D. A. Kenny, "The moderator-mediator variable distinction in social psychological research: Conceptual, strategic, and statistical considerations," Journal of Personality and Social Psychology, vo. 51, no. 6, pp. 1173-1182, 1986

[47] V. Victor, J. J. Thoppan, R. J. Nathan, and F. F. Maria, "Factors Influencing Consumer Behavior and Prospective Purchase Decisions in a Dynamic Pricing Environment-An Exploratory Factor Analysis Approach," Social Sciences, vol 7, no. 9, 2018, doi: 10.3390/socsci7090153.

[48] W. Akhtar and M. Husnain, "Factor that effect on consumer behavior: The case of boarding students," Journal of Progressive Research in Social Sciences (JPRSS), vol. 2, no. 2, pp. 71-79, 2015. 
[49] A. Setyawan, N. Noermijati, S. Sunaryo, S. Aisjah, "Green product buying intentions among young consumers: extending the application of theory of planned behavior," Problems and Perspectives in Management, vol. 16, no. 2 , pp. 145-154, 2018.

[50] S. Gunawan, "The Impact of Motivation, Perception and Attitude toward Consumer Purchasing Decision: A Study Case of Surabaya and Jakarta Society on Carl's Junior," iBuss Management, vol. 3, no. 2, pp. 154-163, 2015.

[51] A. Mensah and R. D. Mensah, "Effects of Service Quality and Customer Satisfaction on Repurchase Intention in Restaurants on University of Cape Coast Campus," Journal of Tourism, Heritage \& Services Marketing, vol. 4, no. 1, pp. 27-36, 2018, doi: 10.5281/zenodo.1247542.

[52] Saling, et al., "Effect of service quality and marketing stimuli on customer satisfaction: the mediating role of purchasing decisions," J. Bus. and Manage. Sci., vol. 4, no. 4, pp. 76-81, 2016. 